\title{
A Case of Immune Thrombocytopenia After COVID- 19 Vaccination: Coincidental or Causal Effect? Running Title: ITP After COVID-19 Vaccination
}

\section{Ernesto Vigna}

Hematology Unit AO of Cosenza

Daniele Caracciolo

Hematology Unit AO of Cosenza

Enrica Martino

Hematology Unit AO of Cosenza

Francesco Mendicino

Hematology Unit AO of Cosenza

Eugenio Lucia

Hematology Unit AO of Cosenza

Virginia Olivito

Hematology Unit AO of Cosenza

Rosellina Morelli

AO of Cosenza

Massimo Gentile ( $\square$ massim.gentile@tiscali.it)

Hematology Unit AO of Cosenza https://orcid.org/0000-0002-5256-0726

\section{Research Article}

Keywords: ITP, Vaccine, COVID-19

Posted Date: May 24th, 2021

DOl: https://doi.org/10.21203/rs.3.rs-448522/v1

License: (1) (1) This work is licensed under a Creative Commons Attribution 4.0 International License.

Read Full License 


\section{Abstract}

The discovery and the introduction of different vaccines in the therapeutic armamentarium against SARSCoV-2 represents a big hope in the fight against the pandemic. However, safety of SARS-CoV-2 vaccination is continuously monitored for the emergence of potential new side effects, such as recently reported thrombotic events, after the use of certain types of vaccines. In this context, we report a case of 31-year-old woman who developed immune thrombocytopenia (ITP) after 3 weeks from receiving SARSCoV-2 vaccine. She developed significant widespread petechiae and gum bleeding, with severe thrombocytopenia documented at her hemogram. Over a 10-day period, thrombocytopenia was treated first with high dose corticosteroids, intravenous immunoglobulin and platelet transfusions, without a platelet response. Two days later, she received the TPO-mimetic and after three days, his platelet count began to rise reaching the normal range 18 days from her admission to our Hematology department. These findings cannot actually elucidate if vaccination was causal or coincidental effect of ITP, but further highlights the need of additional pharmacovigilance studies to empower SARS-CoV2 vaccine efficacy.

\section{Introduction}

Immune thrombocytopenia (ITP) is an immune-mediated hematologic disorder, characterized by isolated thrombocytopenia (peripheral blood platelet count less than $100 \times 109 / L)(1)$, without a clinically apparent cause. Among involved mechanisms, the presence of platelet-directed antibodies and decreased bone marrow production are considered the driver events of ITP pathogenesis. ITP cases have been described following several viral infections, including cytomegalovirus (CMV), hepatitis B/C viruses (HBV/HCV), varicella zoster virus (VZV), human immunodeficiency virus (HIV), and most recently, following COVID-19. Furthermore, rare cases of ITP were observed after measles-mumps-rubella (MMR) and varicella vaccines, but the real incidence of secondary ITP after other types of vaccines is almost unclear.

We here present the case of a 31-year-old female developing, after 3 weeks from SARS-CoV2 vaccination, a severe ITP refractory to corticosteroids and IVIGs, treated with thrombopoietin (TPO) mimetic.

\section{Case Report}

A 31-year-old healthy woman with no prior drug use, received the COVID-19 vaccine through his work as pharmacist employee. After 3 weeks, post-vaccination, she presented to the emergency room due to the occurrence of widespread petechiae and gum bleeding. She did not report recent respiratory and gastrointestinal symptoms or a history of infections. She had not personal history of bleeding or autoimmune disease, while she reported that her father had chronic myelogenous leukemia and vitiligo. Vital signs were normal, no hepatic or splenic enlargement was observed, no focal neurological deficits were noted. Laboratory tests revealed normal white-cell count $(W B C=6.240 / \mu l)$, hemoglobin $(12 \mathrm{~g} / \mathrm{dl})$, 
and severe thrombocytopenia with a platelet count of 1000/ul. Morphologic analysis of peripheral blood smear confirmed thrombocytopenia, without clumping.

Her PCR assay was negative for SARS-CoV-2. One month prior to receiving the vaccine, the patient was evaluated for a routine laboratory screening for her job, and complete blood count reported normal platelet count of 200.000/uL.

At the emergency department, the following labs were normal or negative: creatine, electrolytes, bilirubin, LDH, haptoglobin, prothrombin time, partial thromboplastin time, fibrinogen, aspartate aminotransferase and alanine aminotransferase and total protein. In addition, she was negative for Hepatitis B, Hepatitis C antibody, HIV and Epstein-Barr Virus serology.

Bone marrow biopsy demonstrated absence of immature cells, normocellular trilineal hematopoiesis with strong increase of megakaryocytes. Flow cytometry was normal. A computerized tomography (CT) total body scan did not show organs hemorrhagies or lymphoadenomegalies. Autoimmunity tests performed on day 2 for anti-nuclear antibody (ANA), anti-extractable nuclear antigen (ENA), antineutrophil cytoplasmic antibody (ANCA), rheumatoid factor (RF), anti-dsDNA, anti-smooth muscle antibody (ASMA), anti-Platelet (ab-PLT), anti-Thyroglobulin (anti-Tg) and anti-Thyro peroxidase (anti-TPO) were normal.

On the basis of clinical presentation, a platelet count $<100.000 / \mathrm{uL}$, and the exclusion of other causes of thrombocytopenia, a diagnosis of ITP was made (1).

At this point, the patient was admitted to our Hematology department and a therapy with platelet transfusion, high dose corticosteroids (methylprednisolone $1 \mathrm{mg} / \mathrm{kg} /$ day) and intravenous immunoglobulin at $1 \mathrm{~g} / \mathrm{kg}$ for 2 days, was started (Fig. 1).

On day four, petechiae and oral bleeding decreased, and the platelet count was 57.000/uL. However, after 11 days from start of therapy, epistaxis episode occurred, hemogram showed very low platelet count with PLT 9.000/ul, and the patient was started again on platelet transfusion (Fig. 1).

At that time, in consideration of refractory ITP to standard therapy with corticosteroids or immunoglobulins, eltrombopag (50 mg) treatment was started. On day 18, the patient's platelet count normalized to $150.000 / \mathrm{uL}$, with disappearance of any bleeding symptoms and she was admitted to clinical-laboratoristic follow-up (Fig. 1).

\section{Discussion}

Previous studies reported only mild or moderate side effects after the Covid-19 vaccines (2-3). To the best of our knowledge, this is the first Italian published case, of a young patient with negative prior clinical history, experiencing ITP after Covid-19 vaccine.

The temporal onset of the patient's presentation 3 weeks from vaccine administration strongly suggests, but not proves, a correlation between the vaccine and the patient's ITP. 
However, actually we could not exclude that this diagnosis was coincidental with vaccine administration. Indeed, among all participants to Pfizer-BioNTech and Moderna trials, no ITP was reported, although post vaccination blood work was not mandated (4).

The real incidence of secondary ITP after other types of vaccines is almost unclear. Indeed, rare cases of acquired immune thrombocytopenia was described after measles- mumps-rubella (MMR) and varicella vaccines and the only case-controlled study in this field did not showed a significant increase in ITP after 1 year from vaccination (5).

Although the relationship between COVID-19 vaccination and ITP was actually unclear, different mechanisms could be invoked to explain this phenomenon. In fact, it is conceivable that in our case platelet-directed immune response may have been triggered by injected oligonucleotides, or poly-ethyleneglycol of the nanoparticles, which produced a novel antigen after their attachment on a small number of platelets (6).

\section{Conclusion}

This case report does not diminish the enormous efficacy and safety of COVID-19 vaccination, but highlights the need of additional surveillance to evaluate the true incidence of post vaccination thrombocytopenia and the correct management of vaccination in patients with pre-existing ITP.

\section{Declarations}

\section{Availability of data and material}

All available information is contained within the manuscript.

\section{Acknowledgements}

We thank the patient for granting us permission to publish this information.

\section{Author contributions}

EV and MG had full access to all of the data of this case and take responsibility for the integrity and accuracy of the data. Concept and design: EV, MG, and DC. Acquisition, analysis, or interpretation of data: all authors. Drafting of the manuscript: all authors. Critical revision of the manuscript for important intellectual content: all authors. Supervision: EV and MG.

\section{Funding}

This manuscript was not funded.

\section{Compliance with ethical standards}




\section{Conflict of interest}

On behalf of all authors, the corresponding author states that there are no conflicts of interest.

\section{Consent for publication}

Written informed consent was obtained from the patient for publication of this case and any accompanying images. A copy of the written consent is available for review by the Editor of this journal.

\section{References}

1. Neunert C, Terrell DR, Arnold DM, Buchanan G, Cines DB, Cooper N, Cuker A, Despotovic JM, George JN, Grace RF, Kühne T, Kuter DJ, Lim W, McCrae KR, Pruitt B, Shimanek H, Vesely SK. American Society of Hematology 2019 guidelines for immune thrombocytopenia. Blood Adv. 2019 Dec 10;3(23):3829-3866.

2. Walsh EE, Frenck RW Jr, Falsey AR, Kitchin N, Absalon J, Gurtman A, Lockhart S, Neuzil K, Mulligan MJ, Bailey R, Swanson KA, Li P, Koury K, Kalina W, Cooper D, Fontes-Garfias C, Shi PY, Türeci Ö, Tompkins KR, Lyke KE, Raabe V, Dormitzer PR, Jansen KU, Şahin U, Gruber WC. Safety and Immunogenicity of Two RNA-Based Covid-19 Vaccine Candidates. N Engl J Med. 2020 Dec 17;383(25):2439-2450.

3. Jackson LA, Anderson EJ, Rouphael NG, Roberts PC, Makhene M, Coler RN, McCullough MP, Chappell JD, Denison MR, Stevens LJ, Pruijssers AJ, McDermott A, Flach B, Doria-Rose NA, Corbett KS, Morabito KM, O'Dell S, Schmidt SD, Swanson PA 2nd, Padilla M, Mascola JR, Neuzil KM, Bennett $H$, Sun W, Peters E, Makowski M, Albert J, Cross K, Buchanan W, Pikaart-Tautges R, Ledgerwood JE, Graham BS, Beigel JH; mRNA-1273 Study Group. An mRNA Vaccine against SARS-CoV-2 Preliminary Report. N Engl J Med. 2020 Nov 12;383(20):1920-1931.

4. Baden LR, El Sahly HM, Essink B, Kotloff K, Frey S, Novak R, Diemert D, Spector SA, Rouphael N, Creech CB, McGettigan J, Khetan S, Segall N, Solis J, Brosz A, Fierro C, Schwartz H, Neuzil K, Corey L, Gilbert P, Janes H, Follmann D, Marovich M, Mascola J, Polakowski L, Ledgerwood J, Graham BS, Bennett H, Pajon R, Knightly C, Leav B, Deng W, Zhou H, Han S, Ivarsson M, Miller J, Zaks T; COVE Study Group. Efficacy and Safety of the mRNA-1273 SARS-CoV-2 Vaccine. N Engl J Med. 2021 Feb 4;384(5):403-416.

5. Grimaldi-Bensouda L, Michel M, Aubrun E, Leighton P, Viallard JF, Adoue D, Magy-Bertrand N, Tisserand G, Khellaf M, Durand JM, Quittet P, Fain O, Bonnotte B, Morin AS, Limal N, CostedoatChalumeau N, Morel N, Pan-Petesch B, Decaux O, Mahevas M, Ruel M, Sacre K, Lefrere F, Abenhaim L, Godeau B; PGRx Immune Thrombocytopenia Study Group. A case-control study to assess the risk of immune thrombocytopenia associated with vaccines. 2012 Dec 13;120(25):4938-44.

6. Althaus K, Marini I, Zlamal J, Pelzl L, Singh A, Häberle H, Mehrländer M, Hammer S, Schulze H, Bitzer M, Malek N, Rath D, Bösmüller H, Nieswandt B, Gawaz M, Bakchoul T, Rosenberger P. Antibodyinduced procoagulant platelets in severe COVID-19 infection. 2021 Feb 25;137(8):1061-1071. 
Figures

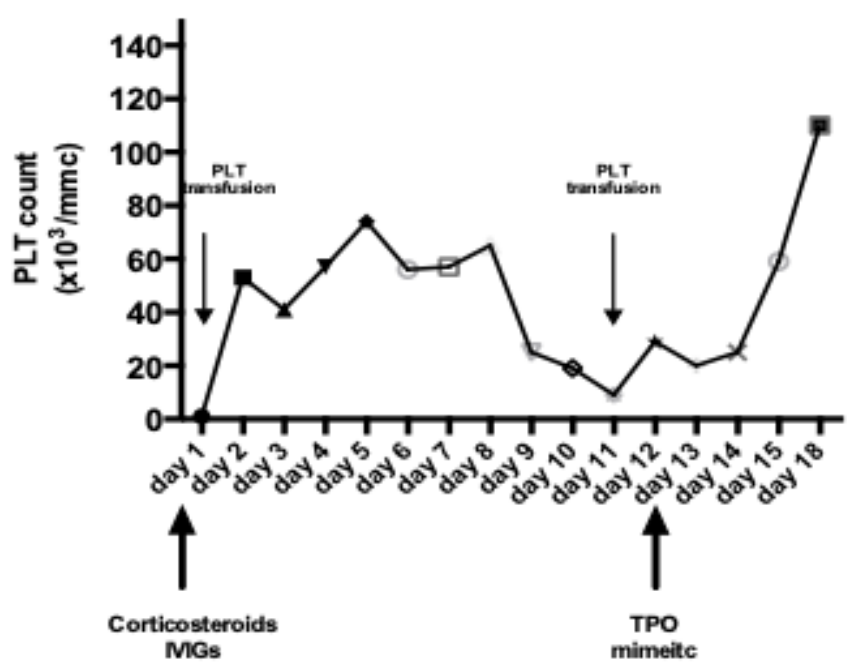

Figure. 1

\section{Figure 1}

Graph depicting patient's platelet count trend during the treatment 